doi: 10.3935/rsp.v26i3.1668

\section{EMES-OVA MEĐUNARODNA ISTRAŽIVAČKA KONFERENCIJA O SOCIJALNOM PODUZETNIŠTVU: ODRZ̆IVI RAZVOJ KROZ SOCIJALNO PODUZETNIČKU, ZADRUŽNU I DOBROVOLJNU AKCIJU}

Sedma po redu EMES-ova međunarodna istraživačka konferencija o socijalnom poduzetništvu ovaj put održana je u suorganizaciji EMES-a ${ }^{1}$, EMPOWER-SE COST akcije $^{2}$, FairShares Instituta za zadružno socijalno poduzetništvo $(\mathrm{FSI})^{3}$ i Centra za regionalnu ekonomsku i socijalnu suradnju $(\mathrm{CRESR})^{4}$ na sveučilištu Sheffield Hallam (Sheffield, Velika Britanija) na kojem se ujedno konferencija i održala od 24. do 27. lipnja 2019. godine.

Tema ovogodišnje konferencije odražavala je glavno pitanje - »Koja je uloga socijalnog poduzetništva, zadruga i dobrovoljnih akcija u rješavanju, podrivanju i transformaciji održivog razvoja? $\ll^{5} U$ toj perspektivi razmatralo se više tema od koji su neke bile siromaštvo i nejednakost; kvaliteta života; okoliš i eko-sustavi i upravljanje održivim gospodarstvima. Kako bi se raspravilo o različitim područjima i disciplinama, konferencija je bila usmjerena na deset tematskih blokova. Njih ćemo ukratko opisati kako ne bismo ulazili u pojedinačna izlaganja koja su bila brojna, s obzirom da tradicionalno EMES konferencije posjećuje više stotina sudionika iz nekoliko desetaka zemalja i sa svih kontinenata.
Prva tematska linija nosila je naslov Koncepti i modeli socijalnog poduzetništva, zadružnog i dobrovoljnog djelovanja unutar koje se htjelo odgovoriti na pitanje što mislimo da je socijalno poduzeće i što mislimo da bi ono trebalo biti. U drugoj se raspravljalo o resursima za socijalnu, zadružnu i dobrovoljnu akciju, posebice kako se mijenja okruženje financiranja, socijalnog financiranja i zadružnog kapitala i kakav je to utjecaj imalo na područje. Socijalne inovacije i poduzetništvo je bila treća tematska linija koja je sagledavala kako različite istraživačke zajednice koje proučavaju treći sektor uokviruju socijalne inovacije. Kakvu ulogu socijalno poduzetništvo ima u pružanju mjesta radikalnim oblicima demokracije koji dovode u pitanje kapitalistički sustav, tržišnu ekonomiju i političke institucije bilo je pitanje o kojem se raspravljalo u četvrtoj tematskoj liniji - Socijalno poduzetništvo kao mjesto radikalnih oblika demokracije, sudjelovanja i djelovanja. Peta tematska linija - Višerazinska vladavina $i$ ekosistemi za socijalno poduzetništvo $i$ održivi razvoj razmatrala je kako ljudi participiraju u vladavini socijalnih poduzeća. Nadalje, Javna politika i pravni okviri za socijalna poduzeća sagledavali su se u sljedećoj, šestoj, sesiji gdje se pozornost usmjerila na regulatorne i javno-političke aspekte različitih zemalja i regija. Sedma sesija proučavala je koncepte zajedničkih dobara i kolaborativne ekonomije te kakav doprinos imaju civilnom obnavljanju. Društvena solidarnost i transformativni pokreti bili su osma tematska linija u kojoj se htjelo analizirati izazivaju li oni i na koji način neoliberalnu hegemoniju. Deveta tematska

\footnotetext{
* Informacije o organizaciji na: https://emes.net/. EMES je najznačajnija mreža sveučilišnih istraživačkih centara $\mathrm{i}$ individualnih istraživača, te najveća istraživačka mreža koja se bavi pitanjima socijalnog poduzetništva.

${ }^{2}$ Dodatne informacije o Akciji mogu se naći na: http://www.empowerse.eu/.

${ }^{3}$ Više informacija na: http://fsi.coop/.

${ }^{4}$ Više informacija na: https://www4.shu.ac.uk/research/cresr/.

${ }^{5}$ Detaljni program konferencije može se pronaći na: https:/emes.net/content/uploads/events/7th-emes-international-research-conference-on-social-enterprise/7EMESconf_25June19.pdf.
} 
linija bila je fokusirana na supstantivnu ekonomiju i pristupe istraživanju i praksi socijalnog poduzetništva inspirirane Polanyjem. Konačno, zadnja tematska linija usmjerila se na epistemološke, metodološke i pedagoške inovacije/napretke u socijalnom poduzetništvu s glavnim fokusom na to kakve su prilike za kritička istraživanja i učenje u polju kojim dominiraju utjecajni »zagovornici«.

Na konferenciji je održano nekoliko plenarnih izlaganja i panela koja su bila usklađena s glavnom temom konferencije. Prvo je bilo naslova »Može li socijalno poduzetništvo biti sredstvo održivog razvoja?« na kojem su sudjelovali Rory Ridley-Duff, Luciane Lucas dos Santos te Nadia Johanisova. Zatim smo drugog dana imali panel »Što i kako socijalno poduzetništvo, zadrugarstvo i dobrovoljna akcija doprinose ciljevima održivog razvoja? « na kojem su sudjelovali Angela Eikenberry, Sonja Novkovic i Marthe Nyssens. Te naposljetku završni panel je za temu imao »Je li socijalno poduzetništvo sredstvo neoliberalizma?« te su na njemu sudjelovali Jo Barraket, Julian Le Grand i Álvaro Porro.

Nekoliko je projekata/istraživanja koji su imali globalnije predstavljanje na konferenciji. Prvi je bio International Comparative Social Enterprise Models - ICSEM projekt $t^{6}$. Projekt uključuje više od 230 istraživača iz više od 50 zemalja diljem svijeta te je predstavio rezultate globalnog istraživanja socijalnih poduzeća, kroz izlaganje Mapping and Testing Social Enterprise Models Across the World; te nekoliko knjiga koje tematiziraju socijalno poduzetništvo u Aziji te socijalno poduzetništvo u Latinskoj Americi. Uz to najavljene su dvije knjige o socijalnom poduzetništvu u Europi koje će se izdati 2020. godine. Predstavljeni su i napori unutar projekta Mapping of social enterprise and its ecosystem in Europe koji za potrebe Europske komisije provodi mapiranje razvoja socijalnog poduzetništva i struktura njegove podrške diljem Europe? Također, konferencija je predstavila nekoliko panela vezanih za COST Akciju 16206 Empowering the next generation of social enterprise scholars (EMPOWER-SE) koja je i podupirala ovu konferenciju. Paneli su bili vezani za socijalna poduzeća i socijalnu državu u komparativnoj perspektivi.

Zanimljiva je bila i debata urednika časopisa. Na njoj su urednici ili članovi uredništva najrelevantnijih časopisa u području (Social Enterprise Journal, Journal of Co-operative Studies, Nonprofit and Voluntary Sector Quarterly, Voluntas, Review of International Cooperation, Journal of Entrepreneurial and Organizational Diversity, Journal of Social Entrepreneurship) raspravljali da li kada govorimo o socijalnim poduzećima, zadrugama i dobrovoljnim akcijama časopisi premošćuju ili pojačavaju razlike koje postoje u područjima.

Dan prije početka konferencije održan je transdisciplinarni forum. Forum je bio namijenjen sudionicima koji dolaze iz neprofitnih organizacija, zadruga, mreža organizacija i javnog i privatnog sektora, te centara za obuku i obrazovanje. Sesije su obuhvatile teme poput primjene FairShares modela na razvoj socijalnog poduzetništva, socijalnih inovacija u obrazovanju, socijalnih ulaganja s naglaskom na zajednicu, ekonomija u zajednici, stvaranja organizacija koje su pogonjene vrijednostima, premošćivanja jaza istraživača i praktičara ili pak sesiju mreže doktoranada koja je bila okrenuta $\mathrm{k}$ pitanjima mentalnog zdravlja

\footnotetext{
${ }^{6}$ Brojne radovi i rezultati projekta mogu se pronaći na: http://www.iap-socent.be/icsem-working-papers.

${ }^{7}$ Izvještaje o pojedinim zemljama među kojima i Hrvatskoj moguće je pronaći na: https://ec.europa.eu/social/ main.jsp?pager.offset $=5 \& \mathrm{advSearchKey}=$ socnteco\&mode=advancedSubmit\&catId=22\&doc_submit=\&policyArea $=0 \&$ policy AreaSub $=0 \&$ country $=0 \&$ year $=0$.
} 
mladih istraživača. Sastao se i Forum o obrazovanju i osposobljavanju za socijalno poduzetništvo (FETSE).

Socijalna poduzeća prirodno prelaze različite vrste granica, u smislu sektora (javni, poslovni, zadruge, udruge), resursa (resursi s tržišta, javnih nabava ili ugovorenih usluga, darovnica, volonterski resursi itd.) i područja djelovanja. S obzirom na svjetsku interdisciplinarnu perspektivu, ova konferencija okupila je raznolike zajednice znanstvenika i praktičara koji su raspravljali o izazovima koji proizlaze iz održivog razvoja, ali i različitim aspektima djelovanja trećeg sektora kroz perspektive socijalnih inovacija, poduzetništva i akcije solidarnosti i drugih okvira. Ona predstavlja najveću i nezaobilaznu konferenciju za sve one koji rade $\mathrm{i}$ istražuju u ovom području ili će to tek krenuti. U hrvatskim prilikama u kojima se sektor tek razvija, unatoč manjkavostima implementacije Strategije razvoja društvenog poduzetništva 2015.2020., ovakva konferencije može biti izvor inspiracije praktičarima, ali i smjerokaz za razvoj područja donosiocima odluka. Sljedeća prilika za prikupljanje znanja i promišljanje područja bit će 2021. kada će konferenciju ugostiti GESES-istraživačka skupina sveučilišta u Zaragozi (Španjolska).

Doc. dr. sc. Danijel Baturina

Pravni fakultet Sveučilišta u Zagrebu

Studijski centar socijalnog rada 